\title{
COMPARTIMENTUL
}

MASS-MEDIA ȘI COMUNICARE

CZU 32

DOI https://doi.org/10.52388/1812-2566.2021.3(94).10

\section{PRESIDENTIAL RHETORIC AS SOURCE OF SYMBOLIC POLITICS}

\author{
Victor MORARU \\ Doctor habilitat în științe politice, profesor universitar, \\ Membru corespondent al Academiei de Științe a Moldovei, Chișinău, Republica Moldova \\ e-mail:vsm.academy2015@outlook.com \\ https://orcid.org/0000-0002-0322-6086
}

This article focuses on some essential questions concerning the features of the rhetoric of political actors and aims to identify the stylistic hallmarks prevalent utilized in presidential speeches. It was selected for analysis the Barack Obama speech on Remarks by the President Naturalization ceremony on the $4^{\text {th }}$ of July 2012. The speech in question is particularly interesting because it provides a useful insight into how a presidential message can be presented on an issue, which it considers important and current. The discourse is analyzed from the perspective of its inclusion in the action of symbolic politics of the President, taking into account the increasingly pronounced process of symbolizing the political arena. The perception of the problem of immigration in the vision of President Obama is pursued. Particular attention is paid to the complexity of the factors that determine the rhetorical manifestations of the orator's position as a mode of political influence. They are established the conceptual peculiarities of Barack Obama's July 4, 2012 speech, discourse is analyzed through the prism of special syntactic features realized, which promote message transfer and reinforcement of the spirit of the nation, are elucidated the tasks promoted by these hallmarks in delivering the intended messages. The substance of Obama's presidential rhetoric is exemplified by the elucidation of rhetorical means such as parallelism, repetition, metaphors, and so on.

Keywords: rhetoric, President Obama, symbolic politics, presidential rhetoric, rhetorical devices, rhetorical strategies, naturalization ceremony on the $4^{\text {th }}$ of July 2012.

\section{RETORICA PREZIDENȚIALĂ CA SURSĂ A POLITICII SIMBOLICE}

Articolul se axează pe elucidarea unor chestiuni esențiale, referitoare la particularitățile retoricii actorilor politici și ișsi propune să identifice semnele distinctive stilistice predominante, utilizate în discursurile prezidențiale. A fost selectat pentru analiză discursul lui Barack Obama privind declarațiile președintelui la ceremonia de naturalizare din 4 iulie 2012. Discursul în cauză este deosebit de interesant deoarece oferă o perspectivă utilă asupra modului în care un mesaj prezidențial poate aborda o problemă, considerată importantă și actuală. Discursul este analizat din perspectiva includerii lui în arsenalul acțiunii politice simbolice a Președintelui, ținând cont de procesul din ce în ce mai pronunțat de simbolizare a arenei politice. Se urmărește percepția problemei imigrației în viziunea președintelui Obama. O atenție deosebită se acordă complexității factorilor care determină manifestările retorice ale poziției oratorului ca mod de influență politică. Sunt stabilite particularitățile conceptuale ale discursului lui Barack Obama din 4 iulie 2012, acesta este analizat prin prisma instrumentelor sintactice realizate, care promovează transferul mesajului și fortificarea spiritului națiunii. Sunt 
elucidate trăsăturile definitorii ale retoricii în transmiterea mesajului dorit. Substanța retoricii prezidențiale a lui Obama este exemplificată prin elucidarea mijloacelor retorice utilizate, precum paralelismul, repetiția, metaforele ș. a.

Cuvinte-cheie: retorică, președintele Obama, politică simbolică, retorică prezidențială, instrumente retorice, strategii retorice, ceremonie de naturalizare din 4 iulie 2012.

\section{LA RHÉTORIQUE PRÉSIDENTIELLE COMME SOURCE DE POLITIQUE SYMBOLIQUE}

L'article se concentre sur l'élucidation de certaines questions essentielles, concernant les particularités de la rhétorique des acteurs politiques et vise à identifier les caractéristiques stylistiques prédominantes utilisées dans les discours présidentiels. Le discours de Barack Obama sur les déclarations du président lors de la cérémonie de naturalisation du 4 juillet 2012 a été sélectionné pour analyse. Le discours en question est particulièrement intéressant car il fournit un aperçu utile de la façon dont un message présidentiel peut aborder une question, considérée comme importante et d'actualité. Le discours est analysé dans la perspective de l'inclure dans l'arsenal de l'action politique symbolique du président, en tenant compte du processus de plus en plus prononcé de symbolisation de l'arène politique. Cela suit la perception du problème de l'immigration dans la vision du président Obama. Une attention particulière est accordée à la complexité des facteurs qui déterminent les manifestations rhétoriques de la position de l'orateur en tant que moyen d'influence politique. Les particularités conceptuelles du discours de Barack Obama du 4 juillet 2012 sont établies, il est analysé à travers le prisme des outils syntaxiques fabriqués, qui favorisent le transfert du message et la fortification de l'esprit de la nation. Les caractéristiques déterminantes de la rhétorique dans la transmission du message souhaité sont élucidées. La substance de la rhétorique présidentielle d'Obama est illustrée par l'élucidation des moyens rhétoriques utilisés, tels que le parallélisme, la répétition, les métaphores, etc

Mot-clés: rhétorique, Président Obama, politique symbolique, rhétorique présidentielle, instruments rhétoriques, stratégies rhétoriques, cérémonie de naturalisation du 4 juillet 2012.

\section{ПРЕЗИДЕНТСКАЯ РИТОРИКА КАК ИСТОЧНИК СИМВОЛИЧЕСКОЙ ПОЛИТИКИ}

Статья посвящена освещению ключевых вопросов, касающихся особенностей риторики политических акторов, и направлена на выявление преобладающих стилистических отличительных знаков, используемых в президентских речах. Для анализа было выбрано выступление Барака Обамы по поводу заявления президента на иеремонии натурализачии 4 июля 2012 года. Выступление анализируется с точки зрения включения его в арсенал символического политического действия президента с учетом все более выраженного процесса символизации политической арены. Цель заключается в том, чтобы воспринять проблему иммиграции в видении президента Обамы. Особое внииание уделяется комплексности факторов, определяюших риторические проявления позиции оратора как способа политического воздействия. Устанавливаются концептуальные особенности речи Барака Обамы от 4 июля 2012 года, речь анализируется сквозь призму использованных синтаксических средств, способствуюших передаче сообщения и укреплению духа нации. Выясняются определяющие черты риторики в передаче желаемого сообщения. Содержание президентской риторики Обамы иллюстрируется разъяснением используемых риторических средств, таких как параллелизм, повторение, метафоры и т.д. а.

Ключевые слова: риторика, президент Обама, символическая политика, президентская риторика, риторические инструменты, риторические стратегии, иеремония натурализации от 4 июля 2012 z.

\section{Introduction}

Lately, the attention paid by researchers to presidential rhetoric has visibly increased. In the very last year, for example, the subject matter has been widely covered in monographic studies [1], in the pages of specialized journals, such as the „Quarterly 
Journal of Speech”, „Rhetoric \& Public Affairs”, „Presidential Studies Quarterly”, „American Politics Research", in scientific articles [2]. The presidential rhetoric proves to be an interdisciplinary investigative path (integrating political, sociological, linguistic elements, political communication, etc.), opportune for elucidating some socio-political issues of the most stringent topicality. As the experts in the field mentions, ,a key function of presidential rhetoric is to define social reality, and this power to define is a significant presidential resource" [3, p. 607].

The manifestation of this resource is expressly related to the symbolic action. The exploitation of symbolic actions in the interests of politics clearly assists the current political processes. Given, according to Pierre Bourdieu that the social world functions simultaneously as a system of power relations and as a system of symbolic interactions, political relations relate to a certain symbolic order, which causes a significant increase in attention to the symbolic element in political action. The exercise of power becomes inseparably linked to the application of the so-called ,symbolic politics", to the use of its resources, in certain cases, in the interest of strengthening the social cohesion of the population, increasing the legitimacy of the political elite, ultimately subordinating it to political interests [4].

The process of symbolizing the political arena, more and more pronounced lately, consists in the transfer of meanings, implicitly, in the translation into the public sphere of different axiological hierarchies. Thus, the political discourse builds the political space, ensuring the circulation of messages, the framework of understanding and interpreting values, in accordance with the axiological structure adopted. The political process is suitable, in this case, for the explanation through symbolic constructions, whose value share is in direct relation with the existing socio-political conjuncture.
Operating with symbols (or symbolic images), political actors give them determined senses and meanings, which manifest themselves verbally or in other forms. Respectively, the agenda of public debates becomes linked to the ideas, objectives and values imposed by the political actors, in this case, by the president of the country, and at the foundation of his current policy. The construction of reality takes place through the predictive establishment of the perception of the social world, which makes possible the desired concordance of spirits, giving at the symbolic power the characteristic of ,quasi-magical power" [5, p. 410], that is, able through expression to shape reality, to impose vision and faith, to affirm or change the perception of the world, and thus to influence the world. Due to the implementation of the principles of symbolic politics, according Murray Edelman, it takes place the „construction of beliefs about events, policies, leaders, problems, and crises" [6, p. 104]. Consequently, the content of symbolic politics as a form of political communication is subordinated not so much to the understanding of meanings as to the action of persuading, of establishing the parameters of the discursive space of politics, on the basis of which various virtual political realities are formed.

It is therefore interesting to dissect presidential speeches from this perspective. We will continue to refer to one of the discourses given by US President Barack Obama, speech on Remarks by the President Naturalization ceremony on the $4^{\text {th }}$ of July 2012. The text taken for analysis come from the internet website [7].

\section{The conceptual peculiarities of Barack Obama's July 4, 2012 speech}

Barack Obama's rhetorical style is broadly acknowledged to be ,one of the most outstanding examples of communication strategy in recent political oratory" [8, p. 44]. Various researchers 
mention that the American President ,is charismatic, a good listener, attractive and impressive" [9, p. 255], that Barack Obama's speeches ,have been a fruitful source for academic studies in terms of linguistics, persuasive language and discourse analysis" [10, p. 83]. The experts states that Barack Obama's has great skills and his speech is appealing and is captivating the audience, that his speeches is metaphorical and extremely emotional. This circumstance allows the politician to influence the consciousness of the recipients in order to convince them in correctness and plausibility of his views. B. Obama skillfully uses all the possibilities of modern metaphor and other expressive resources of rhetoric, which are revealed as well as possible at the level of interpretive and evaluative comprehension. The tactics of relying on the value system of the recipients, vivid and understandable to everyone images, as well as emotionality allow B. Obama to implement his communicative intention through the successful application of the discursive strategies. This is the opinion of the authors of several studies devoted to the study of B. Obama's presidential rhetoric, to the elucidation of particularities of his rhetoric and figurative language as a means of persuasion [11]. It is generally considered that „Obama's success came through his ability to share with his followers his quality as an almost universal symbol for national optimism and societal inclusion" [12, p. 219].

The qualities of B. Obama's presidential rhetoric were also observed based on the speech chosen for the examination. B. Byrne, for example, stating that ,naturalization ceremonies in United States welcome new citizens who realized their dreams and are making a difference in their lives", emphasizes the way in which Obama knows how to capitalize on the potential of a situation: „These rituals of naturalization are important because of the insights they can reveal about how citizenship of the nation-state is understood. These public rituals of citizenship can tell us both about who is excluded from this conception of citizenship and what forms of citizenship (and the rights which are attached to them) are valued" [13, p. 32]. Additionally, B. Byrne brings the argument that through the naturalization speech and the ceremony Obama is using ,a symbol of the idea of inclusion and democracy" [14]. More specifically, according to Chase Dunn, Obama tries throughout his political speech in a competent way to show and transmit to the audience how important and valuable the immigrants are in America, how meaningful changes they are bringing in the everyday lives [15].

The discourse of the President Barack Obama at the Ceremony on the occasion of July $4^{\text {th }}$ in 2012 and the homage of naturalization of the new American citizens can be internally divided, as it is practiced, we consider, into the following nine parts:

1. The introduction. The $4^{\text {th }}$ of July, the national celebration of United States of America: Obama mentions from the beginning ,what a perfect way to celebrate America's birthday”, together, ,with some of our newest citizens". The President of USA expresses in the discourse, in a very solemn way, feelings of joy and pride for belonging to this country, traditionally faithful to indisputable values: „we are a country that is bound together not simply by ethnicity or bloodlines, but by fidelity to a set of ideas" (paragraphs 1-2).

2. Acknowledging the greatness of American History: „we marvel at America's story”. Obama is direct, using the following phrases: the foundation of USA - „, act of extraordinary audacity”. He praises the beginnings of America and the continuity of the country through the following examples: „From a fragile experiment in democracy to a beacon of freedom that still lights the world. From a society of farmers and merchants to the largest, most dynamic economy in the world" (paragraphs 3-4) 
3. The role and the contribution of immigrants in the history of America. The president Obama says: „Our American journey, our success, would simply not be possible without the generations of immigrants”, enumerating: „immigrants signed their names to our Declaration and helped win our independence. Immigrants helped lay the railroads and build our cities”. „So the story of immigrants in America isn't a story of ,them", it's a story of „us”. Obama employs here the key phrase: „we are a nation of immigrants" (paragraphs 5-6).

4. Affiliation of immigrants, who obtained the title of citizens with the values of all American citizens - „duty, responsibility, and patriotism”. This idea is pronounced in the direct/personal address/accounts to the participants in the ceremony: "Now, all of you get to write the next chapter", This last sentences in the paragraph 6 connects with the personalized address of the president Obama to all: different people, with different itineraries, but united by the oath they took and the thought of writing a next chapter in the history of the country, whose citizens they have now became (paragraphs 7-8).

5. From the pathetism related to the Day of 4th of July to a more familiar style. Obama highlights concrete people's names, with the utterance of the person's name, providing one-two details from the biography and expressing confidence in their future as us citizens (paragraphs 9-12).

6. Building America - is a long road, with edges and impediments, but glorious. Obama also states that with tasks always to be solved: „we're still perfecting our union, still extending the promise of America" (paragraph 13).

7. An objective that determines the ascension: „to keep talented young people who want to contribute to our society and serve our country". An essential concept for achieving this goal is, in President's Obama view that „American dream endures for all those - like these men and women - who are willing to work hard, play by the rules and meet their responsibilities". Another premises would be, as the President announces, the „Dream act" and ,the comprehensive immigration reform", needed for America's further success, which would provide immigrants with opportunities to manifest as citizens. The aims of this excerpt from the speech focuses on conveying the idea of inspiring civic engagement in his audience (paragraph 14).

8. The praise of immigration, the importance for America of the phenomenon of immigration: It is insisted in the speech ,immigration makes America stronger, immigration makes us more prosperous". This statement of President derives from the lesson of 236 years. The explanations go further, and deeper: ,immigration positions America to lead in the $21 \mathrm{st}$ century. And these young men and women are testaments to that. No other nation in the world welcomes so many new arrivals. No other nation constantly renews itself, refreshes itself with the hopes, and the drive, and the optimism, and the dynamism of each new generation of immigrants. You are all one of the reasons that America is exceptional". Obama is concluding his speech reminding the audience that American values persist, and America asserts itself more and more in the world and is a resource of its prosperous future: "You're one of the reasons why, even after two centuries, America is always young, always looking to the future, always confident that our greatest days are still to come" (paragraphs 15-16).

9. The overall message of hope, expressed by exemplifying the personal success of immigrants, important in the context of honoring new American citizens based on the use of another personal success story, in fact, each of the participants in the ceremony could be in place of the nominee (paragraph 17).

The structure of the speech demonstrates its development in a logical and judicious way, ensuring 
a pertinent approach to the problem, based on observations, deductions and reasoned findings, each paragraph deepening and coherently developing the message of the President.

Barack Obama was elected the $44^{\text {th }}$ president of the United States, in probably one of the most difficult periods for his country. The United States is struggling with one of the worst economic crises in its history, and in addition, it has waged two unpopular wars, which have affected the country's reputation as a moral champion of democratic countries.

The President Obama succeeded to impose himself, to mobilize fellow citizens on the road to overcoming difficulties. He inspired trust of American citizens and raised their hopes for the better future. He was eloquent in his political speeches, and there are opinions that ,is no doubt that a great part of Obama's success can be attributed to his inspiring speeches" [16, p. 5].

The different topics, approached by B. Obama (relatively, not so many) in the analyzed speech, converge anyway to a major thought that can be seen in the entire content of the speech. Expressed by a President of a country, it is natural that his speech pursues a major goal, which is configured in an argument: in this case, it is emphasized that we are all a nation; we are united by the same ideals, of the same values, of the same traditions. That we must be united, to show solidarity, only in this way we will be able to achieve new successes, to build our country. Let us all rise to the heights we deserve. The President wants to convey this thought to his audience, but also to all the citizens of the country. It should be noted that he is acting in full compliance with the general principles of presidential rhetoric: to "lead public opinion through rhetoric" [17, p. 8].

Obama redefines the prevalent view of American national identity ,by putting emphasis on sharedideals rather than a shared religion" [18, p. 11]. Moreover, the meeting during the ceremony to celebrate the naturalization action between the President and his fellow citizens is an opportunity to relaunch the idea of national unity. Coincidentally, the celebration of the national holiday, July 4, which each year contributes to strengthening the image of America, along with another ritual, very effective in the symbolic policy of government, such as celebrating the new citizens of the American state, it proves to be very successful in conveying a message of unity. This leads to the strengthening of the rhetorical construction of the American national identity. The president does not say it directly, but suggests that establishing citizenship is a very important step for form a nation. Through Obama's speech, citizens are encouraged to participate in an active way in the advancement of the country. In his speech, B. Obama positions himself, first and foremost, as the bearer of American democratic values, in which he firmly believes and which he also promotes through us naturalized citizens.

To promote the idea of national unity, Obama uses specific elements that are well associated with the American nation. Derived directly from the Declaration of Independence (the text that gave Americans their own national identity and thus united them as a distinct nation), the ideals of equality, freedom, and the pursuit of happiness fit very well into the festive context.

The idea of the important role of migrants in the historic process of building America and the unconditional recognition for immigrants of their status as citizens, if they decide to serve the new homeland firmly and honestly, to fight for it if necessary, is strongly promoted by President Obama. He tends to enhance a sense that the immigrants have shown resilience and can bring benefits to a country. In addition, indeed, the nation narrative built on the contribution of immigrants „is potentially a powerful one for giving new 
citizens in a nation a sense of their place in the new country" [19, p. 47]. For Obama, then, also in this case, ,the future is secure as long as young people understand and engage in the purpose that has united America since its conception" [20, p. 84]. Thus, the idea stated by Frank Luntz in his book „Words That Work: It's Not What You Say, It's What People Hear”: „effective messaging focuses on commonalities between the audience and the message being communicated. By emphasizing a shared experience, the listener is more open to what is being said" [21], finds a proper illustration.

Obama's speech conveys the idea of unity by connecting several details, subordinated to the set of thoughts of the subject. Each paragraph deals with this topic of unity and connection. The word „unity” does not appear in the discourse, but its idea is reflected in words and expressions with similar message.

In his naturalization speech Obama, underlines that immigrants are part of „America's story” and points to the idea used in his speech: „So the story of immigrants in America isn't a story of ,them, it's a story of "us", specifying that ,immigrants helped lay the railroads and build our cities". This takes the audience to recognize that in his naturalization speech Obama is emphasizing a key phrase of his speech about ,a nation of immigrants".

It should be noted that the speech relies on presenting specific examples of immigrants, with a familiar indication of the names Obama lists and which are an illustration of how their dreams come true, with America being a country open to immigration.

For Obama, these naturalized immigrant soldiers were and are ,the ultimate citizen hero because they not only overcame many hardships, as other immigrants did, but they placed their lives on the line to serve and protect the United States" [22, p. 49].

\section{The issue of immigration in Barac Obama's speech}

In the main, the issue of immigration plays a significant role in Obama's speech. It is considered thatPresidentBarackObama,,prioritizedimmigration policy during his tenure" [23, p. 117]. This is also natural, given that for the United States, the issue of migration has always been an issue that has always been present in the public debate, generating multiple discussions and controversial attitudes.

The statistical data present a very relevant situation from this perspective: „More than 44.9 million immigrants lived in the United States in 2019, the historical numeric high since census records have been kept. Immigrants' share of the overall U.S. population has increased significantly from the record low of 4.7 percent in 1970. In 2019, immigrants comprised 13.7 percent of the total U.S. population, a figure that remains short of the record high of 14.8 percent in 1890" [24]. Throughout American history, attitudes toward immigrants (including a sense of fear and a pronounced tendency to exclusion) have been a constant focus on political actors.

Researchers have pointed to the "dual attitude" $[25$, p. 74$]$ on the issue of immigrants, which comes from significant figures in the American politics, including presidents of the United States.

For many years, the anti-immigrant sentiment has dominated presidential speeches. Presidential rhetoric in the late 19th and early 20th centuries portrayed immigrants in an unfavorable light. Several presidents have stated that the American nation and its culture ,is ours and is uniquely American" [26, p. 14], even reaching the polarization of the two concepts invoked. Over the years, this attitude has gradually diminished. Vanessa Beasley, in her book "You, the people: American national identity in presidential rhetoric", concludes thereby that an 
understanding of American identity has been adopted in the rhetoric of presidents, which is both inclusive and exclusive, again President Obama ,was much more inclusive than past presidents in his rhetoric on this matter" [27]. Obama's use of inclusive language, with emphasis on common goals, offers the opportunity to empathize with and mobilize the audience, enhancing the persuasive potential of the message, and contributing to overcoming traditional stereotypes about immigrants.

Unlike his predecessors, such as Ronald Regan, George H. W. Bush, and Bill Clinton, who still admit to differentiating between Americans and immigrants, Barac Obama's rhetoric demonstrates a change in attitudes toward immigrants. Obviously, it's not just the fact that he is the son of an immigrant himself: his father is not a natural born American citizen. But being president, thus realizing the status of one of the most important policymakers, Obama assumes new accents on immigration in the public, political and media agenda setting.

In general, scholars noted in President Obama's vision several times a balanced approach and inclination to consider the full complexity of the immigrant category. Thus, Obama's immigration rhetoric „can be celebrated - emphasizes J. D. Cisneros - because it has not relied as much on nativist appeals as have his predecessors" [28, p. 372]. J. Edwards, for example, writes that for Obama, ,immigrants do more that just earn their citizenship. They serve as the lifeblood of America". According to the quoted author, Obama believes and is convinced that „U.S is a nation of immigrants and immigration is its story" $[29$, p. 46], and ,immigrants have constantly pushed the United States into new boundaries" [30, p. 45]. This is visible in president Obama speech where he describes the industrial development, exemplified by "Google and the iPhone", that gives the understanding to the audience that America is a country that which has enough potential for growth and flowering.
Obama's consistency on the issue of immigrants has manifested itself in many presidential speeches on several occasions. The basic ideas he has promoted over the years come back with a new intensity in each of his speeches. In 2010, in his speech delivered at American University, Obama stated that ,we've always defined ourselves as a nation of immigrants - a nation that welcomes those willing to embrace America's precepts. Indeed, it is this constant flow of immigrants that helped to make America what it is" [31].

The same logical scheme of the message (nation of immigrants - diversity coagulated in unity - the significative role of immigrants in the development of America) - is followed in most of Obama's speeches: in his Remarks at a Naturalization Ceremony for Active Duty Service Members and Civilians in 2013 (,,Immigration makes us a stronger. It keeps us vibrant. It keeps us hungry. It keeps us prosperous. It is part of what makes this such a dynamic country. And if we want to keep attracting the best and the brightest that the world has to offer, then we need to do a better job of welcoming them" [32]); in his Address to the Nation on Immigration, in 2014 (,,our tradition of welcoming immigrants from around the world has given us a tremendous advantage over other nations" [33]); at Jerusalem International Convention Center, in 2013 (,America is a nation of immigrants. America is strengthened by diversity" [34, p. 48]), at Del Sol High School in Las Vegas, in 2013 (,We define ourselves as a nation of immigrants. That's who we are, in our bones. The promise we see in those who come here from every corner of the globe, that's always been one of our greatest strengths. It keeps our workforce young, it keeps our country on the cutting edge, and it's helped build the greatest economic engine the world has ever known" [35]).

Afore his inauguration speech Obama said that America is a ,patchwork" nation that includes 
people of many different cultures [36] and „,views this variety as a strength" [37, p. 14]). Excerpts from messages produced in the same key can also be mentioned here, when he states ,we know that immigrants have always been the engine of our economy, starting some of our greatest companies and pioneering new industries" [38], when they qualify immigrants as carriers ,of new hopes and new dreams, new ideas and new optimism about our future. That will make us stronger. That's how we'll make sure that our best days are ahead of us and not behind us" [39].

It should be noted that addressing words of encouragement to immigrants who have become citizens of America, the American president always remembers the need for the great responsibility he assumes the new citizens. Emphasizing the evolving roles of immigrants, he highlights that immigration, which ,generates the most passion and controversy", is, in his view, a phenomenon that must be taken with the utmost seriousness: „Even as we are a nation of immigrants, we're also a nation of laws [40].

\section{Rhetorical strategies in Barack Obama's speech}

The positive strategy that fully characterizes the rhetoric he uses in his speech President Obama ensures the success of receiving the message: when the speaker talks about the future of the nation, of the country, of the world and demonstrates the responsibility for this future, directly involving the audience and appealing to its feelings, takes place the influencing the audience and attracting them to it.

Traditionally, the speech of a public figure - in this case, the speech of the President of the country - it is conceived in accordance with the need to perform the functions of the speech, among which we mention the function of integration (which consists in affirming the unity of the nation being realized by including in the text explicit markers as the people, citizens, my fellow Americans, our, we, us, our American people, Americans, nation). According to some scholars, such a function could be related to the unification and cohesivation strategy [41, p. 1183]. This function of integration is determined, as in other presidential speeches, by the nature and circumstances of public intervention [42]. The language of speech, therefore, must be consonant with the goal of speech, respectively, to contain connotations of inclusion. In its manifest form, the function of integration is realized in the urge, addressed to the audience (,making sure the American dream endures for all those - like these men and women - who are willing to work hard, play by the rules and meet their responsibilities").

We can see this in the number of times inclusive language was used in Obama's speech: the words „we” appears approximately 25 times, ,our” 18 times, „us" 5 times, and „you” + “your” 30 times ( „I” was used in only 4 cases). According to the researchers, ,in political discourses, the strategic employment of we-groups (we, our and us) serve to establish a unified relationship between politicians and the public ... the use of these devices not only unify the orators with the audience but also they identify themselves as one belonging to the society, narrowing or bridging the invisible gap" [43, p. 1183]. Resorting to the inclusive „we”, Obama, ,regards himself as a member of the society to which he speaks. Whether he talks about the preceding accomplishments or the future plans, the orator asserts them to represent unity and commonality, which means that he splits responsibility for everything being mentioned to the audience" [44, p. 1184].

For comparison, in Obama's 2014 speech [45] the words ,we" appear approximately 35 times, "our" 22 times, „us" 16 times, and “you ” + , your” 9 times [46]. And in the inaugural speech, the use of „we" 91 times, „our” 61 times, ,us” 22 times is attested. Thus, the last two speeches show a stronger manifestation of the official position as opposed to 
the speech produced in the more familiar conditions of the celebration of the new citizens. However, the conversational strategy is realized, from the recorded data it is clear that ,the higher energy points typically have more inclusive language”, that „Obama's use of inclusive language plays an important role in creating a powerful message that resonates with the audience. It does so by creating a bridge between both him and anyone listening to him speak. His use of words such as „we”, „our”, and „us” help spur energy and inspire the crowd... he uses the word „us", to signify how we are all in this together as citizens" [47].

Through the use of the mentioned pronouns, the itinerary of the discourse becomes obvious: from „I" more and more to "us". And the pronoun ,our" too performs a unifying task in public speeches. This is one of the traditional arguments of presidential rhetoric. Obama uses the word „I" or „Me" no more then a few times (even if he mentions that ,It is an honor for me to serve as your Commanderin-Chief'). He is not about himself in this Festive moment. Obama talks about the American People, the American citizens. Even as he greets attendees at the ceremony, Obama uses the pronouns „we" and not „I", putting his own personality in the background and emphasizing his sense of belonging to the country, ,he does not patronize his listeners, and makes them feel knowledgeable" [48, p. 237]. The innumerable references to „us" and „we" become in his discourse the component of that goal to which America must align itself, and prosperity must all be done together.

At the core, the opinions of the experts converge on the fact that ,politicians turn to the idea of community to support their future actions because the argument for plurality is stronger and more positive compared to individual authority... The purpose of such a discursive strategy is to allow the highest possible degree of shared experience or identification of the speaker with the audience [49, pp. 150-151].

Another peculiarity of Obama's rhetoric is the exploitation of the function of inspiration (motivation), which consists in enlivening the nation for the cause of prosperity and glorifying traditional values. In the performance of his duties, the President must inspire the audience with confidence in a better future, urge them to participate resolutely in the common cause, and send them a sense of pride in being American: „You are all one of the reasons that America is exceptional", contributing to the audience's awareness of patriotic emotions.

The phrases and words in the patriotic lexicon naturally appear in Obama's language: democracy, Declaration (of Independence), the Constitution, Philadelphia, the colonies, the founders, celebrate America's birthday, values, win, success, freedom, citizen, citizenship, nation of laws, free, prosperous. These references leaves an impression that we are all in this together.

The nation also achieves unity by sharing the past. The historical evocations contained in Obama's speech serve as arguments that guide the audience and mobilize it to overcome difficulties: „From a string of 13 colonies to 50 states from sea to shining sea. From a fragile experiment in democracy to a beacon of freedom that still lights the world. From a society of farmers and merchants to the largest, most dynamic economy in the world. From a ragtag army of militias and regulars to you - the finest military that the world has ever known. From a population of some 3 million - free and slave - to more than 300 million Americans of every color and every creed".

The incentive to action also contains the following passage from the speech: „On that July day, our Founders declared their independence. But they only declared it", following an evocation of the difficulties the country went through, and the 
formulation of the objective: ,And even now, we're still perfecting our union, still extending the promise of America".

In general, as far as Obama's rhetoric is concerned, it is to notice that throughout the speech, almost in all paragraphs, there are recurrent syntactical and lexical clauses that are used to attract the listeners. The use of the particular stylistic expressions is produced to have a persuasive effect on the audience. Often, the thought is expressed indirectly, implicitly, skillfully suggested.

One relevant rhetorical grammatical device that Obama uses is parallelism, a product of „balanced arrangement achieved through repetition of the same syntactic form" [50], ,the quality or state of being similar to something else. It is a quality or feature that makes something similar to something else" [51]. As a stylistic-syntactic device, parallelism ,is accomplished when a similar syntactic structure is repeatedly used in adjacent phrases, clauses, sentences, or paragraphs" [52, p. 59]. The use of parallelism produces intensifying effects, consisting in the repetition of several words in the same order or in the symmetrical construction of two or more sentences. Parallel constructions calls attention to the wording and can emphasize the phrase's meaning, help the orators make the significance more memorable. Rhetorical devices, such as parallelism are used to improve, to inform and convince the audience through the transmitted messages.

Here are some examples of parallelisms in Obama's speech:

- „Some of you came here as children, brought by parents who dreamed of giving you the opportunities that they had never had. Others of you came as adults, finding your way through a new country and a new culture and a new language".

- „It would take another seven years to win the war. Fifteen years to forge a Constitution and a Bill of Rights. Nearly 90 years, and a great Civil War, to abolish slavery. Nearly 150 years for women to win the right to vote. Nearly 190 years to enshrine voting rights".

- „America is always young, always looking to the future, always confident that our greatest days are still to come".

- „We are a country that is bound together not simply by ethnicity or bloodlines, but by fidelity to a set of ideas".

- „Our American journey, our success...”

In this context, the observation regarding the use of parallel structures in the speeches of the American President seems sensible: ,parallelism is more than anything but Obama's favorite and frequently used weapon to emphasize his theme or create a thoughtprovoking atmosphere" [53, pp. 146].

From parallelism derives, in fact, the repetition, a persuasive device appears to be used frequently in Obama's speech that ,penetrate into the audience's minds" [54, p. 95] to underline in his speech how important immigrants are for America. Saying: „All of you did something profound... All of You chose to serve. You put on the uniform ... some of you deployed into harm's way. You displayed ...", Obama reinforces his speech. The repetition of ,you" refers specifically to people who are participating in building a country of immigrants.

Repetition / reiteration is ,one of the most preferable rhetorical figures of speech which reveals itself in repetition of identical morphemes, words, sentences, and makes the speech swift, rhythmical, expressive and emotional" [55, p. 55] and in this way strengthens its influence upon the audience.

Repetitions are frequent in the analyzed speech, especially from sentence to sentence, or paragraph to paragraph. For example, for expression „We salute” we have 4 repetitions, for the words "America", "Americans" - 21 repetitions. Using these words and its derivatives to speech seems that to serve unification purposes. 
Researchers find that, by its very nature, political discourse aims at persuasion. Emphasis, so omnipresent in political speeches, serves well to this end. One of linguistic realisations of emphasis is repetition, wich generates ,necessary reinforcement of ideas and ideology in listeners, helps the audience feel they belong to a larger group through appealing to shared cultural values (which is a crucial aspect of identity construction and builds a community), and enhances organization of ideas into a coherent and logical message" [56, p. 238], as in the following example, by which a stylistic contrivance was used for concern the appeal to the historical past of the American people: „From a string of 13 colonies to 50 states from sea to shining sea. From a fragile experiment in democracy to a beacon of freedom that still lights the world. From a society of farmers and merchants to the largest, most dynamic economy in the world..."

The task set by the orator is being fulfilled by attracting the attention of listeners to the necessary information through repetition of the same word or phrase, careful selection of vocabulary and linguistic stylistic techniques, as well as appeal to the feelings and emotions of the audience, his values system, as in the examples below: „Immigrants signed their names to our Declaration and helped win our independence. Immigrants helped lay the railroads and build our cities, calloused hand by calloused hand. Immigrants took up arms to preserve our union, to defeat fascism, and to win a Cold War. Immigrants and their descendants helped pioneer new industries and fuel our Information Age, from Google to the iPhone"; ,No other nation in the world welcomes so many new arrivals. No other nation constantly renews itself...”; „You are all one of the reasons that America is exceptional. You're one of the reasons why America...". These repetitions reflect the importance to Obama of the values of patriotism and individual acknowledgement to every person mentioned. Thus, the stylistic procedures help them to place the ideas considered important in the foreground.

In B. Obama's speech, such stylistic figures as anaphora are encountered. The device is aimed to repeating a phrase before each clause. Is like parallel structure, but more specific. When Obama uses the same word at the beginning of multiple sentences in a row, he's doing the anaphora: „It's why we still need... It's why we need...."; „Each of you have traveled your own path to this moment... All of you did something profound..."

The speech also uses antithesis: „the world's oldest democracy, with some of our newest citizens", metaphor - „America - beacon of freedom" and other rhetorical means.

\section{Conclusions}

President Barack Obama's speech on July 4, 2012 provides a pertinent example of presidential rhetoric and of symbolic politics action that has succeeded. Well-structured and thoughtful, the president's speech addressed a topical issue - immigration, treating it with new accents, demonstrating overcoming existing stereotypes and emphasizing the importance of the phenomenon.

The message conveyed by the President proved to be a coherent, suggestive and mobilizing one. The purpose of persuading, informing, announcing one's own vision, connected to the demands of the time and the real needs of the state, to demonstrating the speaker's solidarity with the public were achieved through the skillful use of rhetoric. The rhetorical devices investigated in the article were used as means of persuasion to ensure the effectiveness, clarity and beauty of speech. According to the above, there are several factors that have given Obama the status of a notorious speaker, the success of his speech, and one of the most important has been skillfully applying a variety of rhetorical devices in his speech. 


\section{References}

1. ROWLAND, Robert C. The Rhetoric of Donald Trump: Nationalist Populism and American Democracy. - Kansas: University Press of Kansas, 2021; BATES, Toby Glenn. The Reagan Rhetoric: History and Memory in 1980s America. - Ithaca, NY: Cornell University Press, 2021; JOHNSON, Janet L. Political Rhetoric, Social Media, and American Presidential Campaigns Candidates' Use of New Media. - Lanham: Lexington Books, 2021, and others.

2. LEVENSON, Harvey R. A Treatise on the Trump Presidency Presidential Rhetoric - Words Matter. In: International Journal of Linguistics and Communication (American Research Institute for Policy Development), 2021, Vol. 9, No. 1, pp. 1-8; STUCKEY,Mary E. The Power of the Presidency to Hurt: The Indecorous Rhetoric of Donald J. Trump and the Rhetorical Norms of Democracy. In: Presidential Studies Quarterly, 2020, Vol. 50, Issue 2, pp. 366-391; COLLINS,Phoebe. Presidential Rhetoric and Congressional Support: A Case Study of the Impact of Presidential Rhetoric on Foreign Policy. In: Aleph (UCLA Undergraduate Research Journal for the Humanities and Social Sciences), 2020, Vol. 17, No 1, pp. 11-37.

3. ZAREFSKY, David. Presidential Rhetoric and the Power of Definition. In: Presidential Studies Quarterly, 2004, Vol. 34, Issue 3, pp. 607-619.

4. MORARU, Victor. Resursele simbolice ale puterii. În: Valorificarea experienței României în contextul integrării europene a Republicii Moldova. - Chișinău: ICJPS, 2018. - pp. 55-79.

5. BOURDIEU, Pierre. Sur le pouvoir symbolique. In: Annales. Economies, sociétés, civilisations, 1977, Vol. 32, No 3, pp. 405-411.

6. EDELMAN, Murray. Constructing the Political Spectacle. - Chicago: University of Chicago Press, 1988.

7. OBAMA, Barack. Remarks by the President at Naturalization Ceremony [Electronic resource]. July 04, 2012. Retrieved from:https://obamawhitehouse.archives. gov/the-press-office/2012/07/04/remarks-president-naturalization-ceremony (Accessed 30.10.2021).

8. ESCUDERO, Pilar Guitart (University of Virginia VA). Barack Obama's Inaugural Address: Metaphor and
Values as Captivating Strategies to Celebrate a Presidency. In: Pragmalingüística, 2011, Nr. 19, pp. 44-55.

9. TAMPANGELLA, Terra, ROKHAYATI,Titi (Purworejo Muhammadiyah University, Indonesia). The Analysis of Noun Derived from Adjective Found in Barack Obama's Speech and the Teaching of Grammar. In: JOLLT. Journal of Languages and Language Teaching, 2021, Vol. 9, Issue 2, pp. 250-256.

10. CIRUGEDA, Isabel López, SÁNCHEZ RUIZ, Raquel (Instituto Franklin - UAH). Persuasive Rhetoric in Barack Obama's Immigration Speech: Pre- and PostElectoral Strategies. In: Camino Real. Estudios de las HispanidadesNorteamericanas (Alcala de Henares), 2013, Vol. 5, Nr. 8, pp. 81-99.

11. HORVÁTH, Juraj. Critical Discourse Analysis of Obama's Political Discourse: Paper presented at the International Conference of Language, Literature and Culture in a Changing Transatlantic (2009). Retrieved from: http://www.cs.columbia.edu/ sbenus/Teaching/APTD/ Horvath_CDO_Obama.pdf (Accessed: 5.11.2021); WAGECHE, Irungu, CHI, Changhai (Zhejiang University, China). Conceptual Metaphors and Rhetoric in Barack Obama's and Xi Jinping's Diplomatic Discourse in Africa and Europe. In: International Journal of English Linguistics (Canadian Center of Science and Education), 2017, Vol. 7, Nr. 2, pp. 52-62; MARBUN, Riva Right, PASARIBU, Tiara, PASARIBU, Donna (Universitas HKBP Nommensen, Indonezia). An Analysis Of Presupposition On President Barack Obama's Speech on his First and Second Inaugural Addresses. In: The Episteme. Journal of Linguistics and Literature 2015, Vol. 1 Nr. 2, pp. 158-190, etc.

12. PARLETT, Martin A. Demonizing a President: The „Foreignization” of Barack Obama. - Santa Barbara: ABC-CLIO, 2014.

13. BYRNE, Bridget (Manchester Unversity). Americans in the Making: Myths of Nation and Immigration in Naturalization Ceremonies in the United States. In: COLLeGIUM (Finland), 2017, Vol. 23, pp. 31-49.

14. Ibidem.

15. DUNN, R. Chase (James Madison University). „The Future is in Good Hands": A Pentadic Analysis of President Barack Obama's Farewell Address. In: Kaleido- 
scope: A Graduate Journal of Qualitative Communication Research, 2018, Vol. 17, pp. 73-89.

16. LESZ, Barbara. To shape the world for the better: an analysis of metaphors in the speeches of Barack Obama: Master Thesis. - Tromsø: UIT, 2011. - Retrieved from: https://munin.uit.no/bitstream/handle/10037/3540/thesis. pdf? sequence=1\&isAllowed=y (Accessed 18.10.2021).

17. BEASLEY, Vanessa B. The rhetorical presidency meets the unitary executive: Implications for presidential rhetoric on public policy. In: Rhetoric and Public Affairs, 2010, Vol. 13, Nr. 1, pp. 7-35.

18. WEST, Victoria (Hollins University). A Style of His Own: A Rhetorical Analysis of President Barack Obama's Inaugural Addresses: Undergraduate Research Awards. - Retrieved from: http://digitalcommons.hollins. edu/researchawards. (Accessed 3.10.2021).

19. BYRNE, Bridget. Op. cit.

20. DUNN, R. Chase. Op. cit.

21. PHILIPS, Andrew. The Speech That Changed America: An Analysis of Barack Obama's 2004 DNC Speech [Electronic resource]. Sept. 16, 2020. Retrieved from:https://andrew-philips.medium.com/thespeech-that-changed-america-ae701206da87 (Accessed 30.10.2021).

22. EDWARDS, Jason A. (Bridgewater State University). The Good Citizen: Presidential Rhetoric, Immigrants, and Naturalization Ceremonies. In:AmericanCom municationJournal, 2014, Volume 16, Issue 2, pp. 43-51.

23. ESHBAUGH-SOHA, Matthew, GONZALEZ JUENKE, Eric. The Politics of the President's Immigration Rhetoric. In: American Politics Research, 2022, Vol. 50(1), pp.117-130.

24. BATALOVA, Jeanne, HANNA, Mary, LEVESQU, Christopher. Frequently Requested Statistics on Immigrants and Immigration in the United States [Electronic resource]. February 11, 2021. Retrieved from:https:// www.migrationpolicy.org/article/frequently-requestedstatistics-immigrants-and-immigration-united-states2020 (Accessed 12.12.2021).

25. TINSHE, Sonia, JUNAIDI, Junaidi (English Studies Program, Universitas Indonesia). Who are Americans? Analysis of Obama and Trump's political speeches on immigration. In: CELTIC: A Journal of Culture, English
Language Teaching, Literature \& Linguistics, 2019, Vol. 6, Nr. 2, pp. 73-87.

26. WEST, Victoria. Op. cit.

27. BEASLEY, Vanessa B. You, the people: American national identity in presidential rhetoric. Texas: Texas A\&M University Press, 2004.

28. CISNEROS, J. David. A Nation of Immigrants and a Nation of Laws: Race, Multiculturalism, and Neoliberal Exception in Barack Obama's Immigration Discourse. In: Communication, Culture \& Critique, 2015, Vol. 8, Issue 3, pp. 356-375.

29. EDWARDS, Jason A. Op. cit.

30. Ibidem.

31. OBAMA, Barack. Comprehensive immigrationreform [Electronic resource]. July 01, 2010. Retrieved from:https://www.americanrhetoric.com/speeches/barackobama/barackobamacomprehensiveimmigrationreform.htm.

32. OBAMA, Barack.Remarks by the President at a Naturalization Ceremony for Active Duty Service Members and Civilians [Electronic resource]. March25, 2013. Retrieved from: https://obamawhitehouse.archives.gov/ the-press-office/2013/03/25/remarks-president-naturalization-ceremony-active-duty-service-members-an (Accessed 29.10.2021).

33. OBAMA, Barack.Remarks by the President in Address to the Nation on Immigration[Electronic resource]. November20, 2014. Retrieved from:https://obamawhitehouse.archives.gov/the-press-office/2014/11/20/ remarks-President-address-nation-immigration(Accessed 29.10.2021).

34. OBAMA, Barack. Speech on his Israeli trip to the Israeli Young People, Jerusalem International Convention Center (Jerusalem)March 21, 2013. [Electronic resource]. Retrieved from:https://www.files.ethz.ch/isn/168385/ CDA\%20of\%20PBO $\% 20$ in $\% 20 \mathrm{ME} \% 20 \% 20 \mathrm{~N}$-Africa\%20\%20\%20By\%20Alelign\%20A\%20.pdf(Accessed 29.10.2021).

35. OBAMA, Barack.Remarks on Immigration Reform on January 29, 2013. In: New York Times, 2013, January 30 .

36. New Era of Responsibility. President Obama's Inaugural Address[Electronic resource]. January 20, 2009. Retrieved from: https: // pbamawhitehouse.archives.gov/ 
blog/2009/01/21/president-Barack-obamas-inauguraladdress (Accessed 28.10.2021)

37. WEST, Victoria. Op. cit.

38. President Obama Speech to Mexican Students [Electronic resource]. May 03, 2013. Retrieved from: https://www.c-span.org/video/?312519-1/presidentobama-speaks-mexican-students(Accessed 28.10.2021).

39. OBAMA, Barack.Remarks by the President at a Naturalization Ceremony for Active Duty ServiceMembers and Civilians.

40. Obama, BARACK. Remarks by the President in Address to the Nation on Immigration.

41. KAZEMIAN, Bahram, HASHEMI, Somayyeh (Islamic Azad University, Iran). Critical Discourse Analysis of Barack Obama's 2012 Speeches: Views from Systemic Functional Linguistics and Rhetoric. In: Theory and Practice in Language Studies, 2014, Vol. 4, Nr. 6, pp. 1178-1187.

42. VAIL, Mark. The „Integrative” Rhetoric of Martin Luther King Jr.'S „I Have a Dream” Speech. In: Rhetoric and Public Affairs, 2006, Vol. 9, Nr. 1, pp. 51-78.

43. KAZEMIAN, Bahram, HASHEMI, Somayyeh. Op. cit.

44. Ibidem.

45. OBAMA, Barack. Remarks by the President in Address to the Nation on Immigration.

46. PHILIPS, Andrew. Op. cit.

47. New Era of Responsibility. President Obama's Inaugural address.

48. JANCZYŁO, Arkadiusz (Ateneum-Hign School,
Poland). The role of repetitions in Barack Obama's speech and its Polish translation. In: Forum FilologiczneAteneum, 2020, Nr. 1 (8), pp. 227-240.

49. MORARU, Victor, CIUMACENCO, Valentina. Strategii modale în dezbaterea electorală televizată (studiu de caz). In: Revista de Filosofie, Sociologie şi Ştiinţe Politice, 2016, Nr. 3 (172), pp. 143-154.

50. Parallelism. In: BALDICK, Chris. The Oxford Dictionary of Literary Terms. 4th Edition. - New York: Oxford University Press, 2015.

51. Parallelism. In: RUNDELL, Michael. Macmillan English Dictionary. - Stuttgart: Macmillan Education, 2007.

52. HASSAN, Moayad Mohammad, HUSSEIN, Abbas Lutfi. Stylistic hallmarks of Obama's (2009) and AlMaliki's (2006) Inaugural Addresses. In: International Journal of Linguistics, Literature and Culture, 2021, Vol. 7, Nr. 2, pp. 57-69.

53. FENGJIE, Li, JIA, Ren, YINGYING, Zhang. Analysis of the Rhetorical Devices in Obama's Political Speeches. In: International Journal of Language and Linguistics, 2016, Vol. 4, Nr. 4, pp. 141-146.

54. CIRUGEDA, Isabel López, SÁNCHEZ RUIZ, Raquel. Op. cit.

55. SHEVELEVA, Alla (Far Eastern Federal University, Russia). Lingo-Rhetorical and Socio-Pragmatic Peculiarities in Political Speeches by Barack Obama. In: Intercultural Communication Studies, Vol. 21, Nr. 3, pp. 53-62.

56. JANCZYŁO, Arkadiusz. Op. cit. 